\title{
Managing challenges and cultivating collaborations in Indonesia's knowledge society
}

\author{
Farah Purwaningrum
}

\section{Introduction}

The shift towards a knowledge society in South East Asia has produced different effects in Singapore, Malaysia and Indonesia (see Evers 2003; Hornidge 2007; Hornidge 2011). This paper examines the challenges

faced by Indonesia's knowledge society. It attempts to answer the following research question: what are the current challenges encountered in Indonesia's knowledge society, and what kind of collaborations currently exist?

The paper aims to provide in-depth insights into what unfolds in Indonesia's knowledge society. It employs a qualitative study using relational sociology to integrate macro and micro level findings. By using a conceptual framework, developed by Boehme and Stehr (1986), about the pillars of knowledge society, the study focuses on the key idea of scientisation. The author contends that challenges faced by Indonesia's knowledge society consist of historical, structural and scientisation factors. Scientisation is, in fact, decreasing in Indonesia's knowledge society. Further, the study finds that collaborations are likely to occur if they are based on social ties of friendship and trust. For a real and actual collaboration between academia and a company, the company typically has to make the first move.
Ideally, the conceptual approach to developing a knowledge society in Indonesia or South East Asia should review different alternative (modes) of tapping actors in the knowledge society with science indicators and international collaborations for critical (social) science engagement. Further to this, alternative scientisation approaches should be considered.

The study makes the following contributions. It contributes to scholarly discussion on "knowledge society" from the perspective of scientisation. With changes in the mode of knowledge production affecting the science system as shown in the literature (Gibbons et al. 1994; Loh et al. 2011; Nowotny et al. 2001), this research sheds light on how actors (i.e. governments and academia) may contribute to scientisation. Second, the study contributes empirically to ideas of "modernity" and policymaking in the science sector in Indonesia within the discourse of "knowledge society" by highlighting that, with the diminishing scientific character of research and universities, it is timely to open the discussion on the possibility of other actors, such as industry, producing scientific knowledge.

The structure of the paper is as follows. It will first revisit the conceptualisations of a knowledge society. Next, the methodology used and the approach of the study are outlined. This is followed 
by the empirical components of the paper: the challenges encountered by Indonesia's knowledge society and an analysis of existing collaborations in Indonesia's knowledge society. The conclusion and reflection section sums up the discussion and offers insights on how one can move forward.

\section{Conceptualisations of a knowledge society}

"Knowledge society" has been a subject of discussion among sociologists and research scholars studying higher education and the science system since the late 1960s and early 1970s (see Bell 1973; Hornidge 2012). Generally, a knowledge society can be characterised as an imaginary space where there is a discourse based on intellectual assumptions about the most fruitful focal points for analyses of modern societies (Valimaa and Hoffman 2008). The knowledge society discourse incorporates everything related to knowledge and knowledge production (Valimaa and Hoffman 2008). For sociologists, inquiry into a knowledge society captures how a society capitalises on the knowledge to shift into modern society. Bell contends that the exponential growth of science is seen as the main factor in the shift from an industrialised society to a knowledge society (Bell 1973; see also Weingart 2002).

The term "knowledge society" differs conceptually from "knowledge-based economy" or "knowledge-based society". The similarity lies in the fact that both see knowledge as a driving factor of industrial and societal activity, instead of classical factors of production (Bell 1973; Fischer 2011). However, in a knowledge-based economy, according to the system theory approach, transformations are no longer solely captured as an end result of "creative destruction" by businessmen but as a structural characteristic of knowledge-based economies (Leydesdorff 2012). Further, for policymakers, a "knowledge-based economy" seems to be more realisable than a knowledge society (Hornidge 2012). Singapore and Indonesia, for instance, identified the "knowledge-based economy" as a path to economic survival (Hornidge 2011, Subejo 2010). Another difference is that the discussion of "modernity" is deeply linked with a knowledge society rather than a knowledge-based economy (see Hornidge 2007; Krings 2011). In this paper, the author uses the above observation as the basis of why "knowledge society" offers a more lucid perspective in discussions of modernity regarding capitalisation of knowledge at societal level.

In a contemporary society, knowledge society may be described as a community wherein there is a penetration of scientific knowledge in all spheres. The advancement of science in a knowledge society is characterised by some key features (Boehme and Stehr 1986). The first is scientisation, which is the percolation of scientific knowledge into most areas of social action. The second is professionalisation, which refers to the substitution of types of knowledge with scientific knowledge. The third feature is science emerging as a productive force. The fourth is the development of a new sector of production through the production of knowledge. The fifth is the change of structures of power incorporated in the technocracy debate, and the sixth is the rise of intellectuals as a new social class. Scientific knowledge production and expansion, according to Boehme and Stehr (1986), is one of the pillars of a knowledge society. This study uses the idea of scientisation ${ }^{1}$ (as explicated in the first point) as an analytical lens to grasp how the knowledge society materialised, on the one hand, and the challenges faced by academia in Indonesia, on the other hand. Knowledge society will be viewed and limited to this point in the analysis. Taking into account the idea and the boundaries, the paper defines scientisation as "the spread, usage and production of scientific knowledge in the social world". 2

What is the significance of situating the overall analysis in a knowledge society? The idea of knowledge society is central to the idea of transition in a society - from feudal to modern, for instance. Second, in observing how knowledge is capitalised by actors in the science system, the idea of knowledge society is key to understanding the emerging world (see Stehr 2003 as cited in Mueller 2005). This paper focuses on a knowledge society in South East Asia, specifically in Indonesia. From a knowledge society perspective, there has been a lack of research on how micro and macro changes simultaneously affect scientific knowledge production in Indonesia. Indeed, several studies have discussed the knowledge sector in Indonesia in depth (see Bappenas 2015; Koecker and Saxena 2012). However, the focus has been on innovation systems or how to improve the knowledge sector in comparison with other countries. Notable exceptions are studies by, 
among others, McCarthy and Ibrahim (2011) and Suryadarma et al. (2012), who presented critical empirical findings on the state of social science knowledge production and practices in Indonesia's science system. Nonetheless, both these studies are technical reports and lack theoretical engagement. Further, studies on knowledge society in Indonesia, and South East Asia at large, are of particular interest as they have a few features that are possibly not found in western countries, such as the fact that colonial ties prompted the establishment of universities. In fact, the University of Malaya in Malaysia and the University of Indonesia were both founded in colonial times. Next, professional associations may not be the primary bases for the nurturing of experts in all professions, although they can play a strong role on a case-by-case basis, such as that of Persatuan Sains Sosial Malaysia (Malaysian Social Science Association).

Knowledge society as a contemporary society may be described as a community where there is penetration of scientific knowledge in all spheres (Boehme and Stehr 1986). Regarding this point, Hayek (1945, p.522) reminds us how, nowadays, "it is almost heresy to suggest that scientific knowledge is not the sum of all knowledge". What "scientific" means can be depicted with regard to whether the influence of science is concentrated or dispersed in society at large (Fuller 1998).

Scientisation is one of the features of a knowledge society. Agrawal (2002) uses the term scientisation to refer to three processes of particularisation, validation and generalisation of indigenous knowledge. Particularisation is the identification and separation of useful knowledge. In the next stage the particularised knowledge is tested and substantiated on the basis of criteria deemed fitting by science. Validation is the use of scientific criteria to test and enquire into, and the documentation of these tests. It is also a process of abstraction. Once a particular knowledge is abstracted and validated, it undergoes a process of generalisation. Such process includes cataloguing, archiving and circulation prior to its wider usage. The three stages described are processual, specific to indigenous knowledge and do not mention history. Historians of science also study the process of abstractions and generalisation, when discovering the relation between rules, paradigms and normal science (Kuhn 1970, p.43). How this differs from indigenous knowledge is that in scientific knowledge, learning is gained by conducting science rather than by acquiring the rules for doing it (Kuhn 1970, p.191).

Knowledge has different forms, such as tacit, explicit, local or scientific. This paper is concerned primarily with scientific knowledge, as this typology is inherently tied to scientisation. Several aspects of scientific knowledge are discussed in knowledge management. Theoretical knowledge was postulated by Daniel Bell (1992) and later by Tsoukas (2005) when he conceptualised specialised knowledge, which is supplied by universities, consulting firms and R\&D departments for products. Such specialised knowledge is based on research (Tsoukas 2005). Both of these - theoretical and specialised knowledge - are linked with scientific knowledge. Knowledge management studies remind us that each typology, whether theoretical or specialised, is tied to tacit knowledge. The reason is not only because scientists rely on a characteristic of tacit knowledge which is personal knowledge (see Abrosini and Bowman 2001) but also because there is context (Abrosini and Bowman 2001) in science that could shape the practice and ways of verification (see Agarwal 1995) of knowledge production.

Zellner and Formahl (2002) argue that the scientific process is based on the fundamentals of knowledge that make up its production but are not directly included in the terms of output. They are, instead, of less substantive character. They contribute in terms of channels of knowledge transfer, particularly in science-based industries where such transfer may lead to an orientation of an "application"-based transfer, accentuated in innovation models (Zellner and Formahl 2002, pp.193-194). Knowledge diffusion and knowledge transfer are indeed two topics of importance in knowledge management. Nonetheless, questions of scientific practice and culture of knowledge production are outside the ambit of knowledge management studies. Knowledge management focuses more on problem-solving (see Leonard-Barton 1992); a person-to-person approach, for instance, is more viable for using tacit knowledge to solve problems (Hansen et al. 1999). Scientific knowledge is not always produced with this provision in mind. Producing good scholarship takes time and reflection. Scientists are not consultants working in retail industry, who have to shoulder the pressure of meeting deadlines set by project managers. Instead, academics and scientists are in need of scholarly 
time autonomy which will allow them the freedom to specify how temporal resources should be utilised (Vostal 2013). The question of how knowledge restructures a society and the question of modernity are not dealt with in knowledge management.

How does knowledge restructure a society? It was Bell (1973) who suggested that knowledge restructures the organisation of a post-industrial society, a society characterised by, among others, a shift from commodity production to the tertiary sector (Bell 1973; Hornidge 2007). A more political reading of a knowledge society is that, at the level of nation states, there is a choice of three routes to consider (Castells and Himanen 2001, cited in Valimaa and Hoffman 2008): (i) the Finnish model denoting an open, welfare state-based knowledge society; (ii) the Silicon Valley model which is a market-driven, open society; (iii) and Singapore's model which is an authoritarian model of knowledge society. Although one could refer to a political or a functional reading of knowledge society, it is best to review the quintessential idea of a knowledge society in order to grasp the conceptualisations of knowledge, particularly scientific knowledge, and the impact of such knowledge on society's social structure.

Knowledge, despite its different typologies, does constitute a capacity for action and a model for reality (see Stehr and Ufer 2003). It is increasingly being produced in many other organisations, such as government laboratories and industries, enabling the heterogeneity of production (Loh et al. 2005). There are no longer strict boundaries between these knowledge-producing organisations, and Gibbons emphasised that such barriers are receding further (Gibbons et al. 1994). Hakansta and Jacob (2016) point out that many are in favour of opening up the national science policy making to include actors other than policymakers and researchers.

There is also a shift in the traits that one attributes to firms, factories and laboratories in science institutes or academia (see Leonard-Barton 1992; Knorr-Cetina 1999). Thus, what emerges is a fuzzy and complex picture. The question, inevitably, is aimed in the direction of what is distinctive about universities as a site of knowledge production (Harloe and Perry 2004). The espousal of "new public management doctrine" in universities has led to macro level changes in the majority of western countries (Ylijoki 2014). Such changes have set in motion changes in academia where universities are asked to engage in economic activities and to become active economic actors themselves (Ylijoki 2014; see also Pinheiro and Stensaker 2013; Slaughter and Rhoades 2004). It is no surprise that such market-oriented roles are also visible in Asia/South-East Asia.

Changes are also evident in terms of how knowledge is being produced. Academia's approach to knowledge production is captured in Mode 1 and Mode 2. They shed light on the disciplinary production of knowledge (Gibbons et al. 1994). Mode 1 consists of traditional scholarship of discipline-based knowledge production, which distinguished between what is fundamental and applied. Knowledge being produced is authenticated through the sanction of a clearly defined community of experts/specialists in accordance with their discipline (Gibbons et al. 1994, p.22). In Mode 2 , there is a movement beyond the structure defined by the discipline within the constitution of an intellectual agenda. This includes the manner in which resources are utilised, the means by which research is organised, communication and the evaluation of the result (Gibbons et al. 1994).

There is a process of heterogeneous growth of knowledge where communication assumes a central role in the dynamics of Mode 2. Knowledge production increases as the individuals involved in the genesis of knowledge remain socially distributed (Gibbons et al. 1994, pp.11-14). Lately, older division lines and the separation, for example between universities and industry, have also blurred. The combination of norms and values in different parts of society is an element of the process of diffusion. This also enables further communication with the industry that shares a similar culture and language. The argument proposed by Gibbons et al. is that the parallel expansion of potential knowledge producers combined with the growing requirements of specialist knowledge has created conditions for the emergence of a new mode of knowledge production. For universities and research institutes, this implies a shift in science from predominantly disciplinebased knowledge production to an interactive and interdisciplinary means of knowledge creation, which hinges on the participation of a number of non-scientific actors (Hakansta and Jacob 2016).

The typologies of Mode 1 and Mode 2 are not immune to criticism. A more political reading of knowledge production was offered by Pestre (2003) who argued that, contrary to Gibbons et al. and 
Nowotny et al., the description of Mode 1 cannot be accepted as an accurate feature of the knowledge economy in the west. Knowledge has always mattered significantly to states and to the economic elite, and most knowledge producers have always paid attention to the interests of those elites (see, for instance, Ye and Nylander, 2015). The Russell Group in the UK, for instance, has clustered toptiered universities in the UK. An article in the Guardian in 2013 (The Guardian 2013) reported research by Sutton Trust which identified a link between a child's social class and the likelihood of being able to attend a top-tier university, such as those listed in the Russell Group.

What are the roles of academia? Clark (1998) identifies the assortment of roles that universities have to accomplish. These encompass educating and training students; producing excellent research in accordance with peer-reviewed criteria; innovating to enable an improvement of productivity through collaborative relations with external partners; producing relevant research that meets the client organisation's needs; and making contributions to socio-economic matters in general and adding civic value in the public realm (Clark 1998). The idea of the third mission is also currently surfacing: the recognition that universities have more functions than mere research and teaching that relate to their wider economic, social and civic role (Harloe and Perry 2004; May and Perry 2011). Overall, there are several main tenets that are linked to the changes in universities in western countries (Deem 2001): globalisation, internationalisation, new managerialism, and entrepreneurialism in higher education. The last one calls for academics and administrators to actively find new ways of accessing private sector funds, sometimes beyond the state, or, in other words, how to adjust to changes introduced by "neoliberal governmentality" (Pestre, 2009; see also Pinheiro and Stensaker 2013) to the governance of academic science or academia in general. Research institutes are also involved in knowledge production, as part of academia. While they do not produce graduates, they focus on producing scientific knowledge via research activities either at a basic and/or applied level. In the science and technology system, the research institute's role is pivotal to scientific knowledge production and, in certain cases, commercialisation of research (Chen and Kenney 2007). This paper will consider academia as broadly encompassing research institutes and universities in Indonesia. The following sections discuss the methodology utilised.

\section{Methodology used in the exploratory study}

This study uses a relational sociological approach in that it combines macro sites and micro sites. Relational sociology is defined as the discovery of mechanisms in relational/interaction conditions and dynamics that recur in social life, with relatively predictable outcomes (Crossley 2010). Crossley (2010) sees agency and structure as effectively coexisting elements of the social world with substantial or lesser salience in different contexts. On the basis of this standpoint, the author attempts to integrate micro- and macro sociologies (Knorr and Cicourel 2014) in the following manner: the analysis was carried out by integrating the analysis and findings from a macro site in Jakarta Greater Area and a micro site in Bekasi District and Puspiptek Serpong, Tangerang.

As mentioned earlier, to acquire a conceptual understanding of knowledge society, the study focuses on sectors of policy-makers ${ }^{3}$ when considering scientisation in Indonesia. The author corresponded with the policy-makers via phone calls and emails in 2009 and 2010. Initial contact was established when the author was invited to attend an integrated workshop on the "Regional Innovation System" organised by RISTEK from 24 to 26 May 2010, and a business meeting on "Potential and Investment Opportunities in Central Java" organised by the Business Innovation Center and Provincial Government of Central Java on 23 October 2010.

Conceptually, the paper employs qualitative analysis based on empirical data and documentary analysis. The data were collected through fieldwork in Indonesia in 2010-2011. Interviews were transcribed, observations were recorded through field notes, and documentary analysis was thoroughly conducted. Semi-structured interviews were carried out, lasting one to two hours, with policy-makers and researchers from a research organisation and from a company. In such interviews, while the questions are determined beforehand, the author has more liberty to explore the answers in a way that would appear prejudicial to the aims of standardisation and comparability (May 2001, p.123). The 
main aim is to elaborate on specific topics not found in literature reviews and/or documentary analysis but cited frequently during previous interviews. In order to obtain rich data, 18 policy-makers in ministries managing science systems in Indonesia were interviewed. They were all located in the capital city of Jakarta and were regarded as experts on this issue. In addition to this, in-depth interviews were conducted with five senior employees in two organisations: a company and a researchbased organisation. Interviews were carried out in the Indonesian language and, in one instance, in English.

In addition to the interviews, the author also recorded key observations at business meetings. These were documented in fieldnotes at seven meetings held between May 2010 and November 2010. These meetings took place in the West Java Province and Jakarta Province, Indonesia. ${ }^{4}$ Both the interviews and the observations were conducted with the informed consent of the participants. Documentary analysis was undertaken using secondary government documents and policy reports spanning the period 2010-2016. Specifically, the documentary data analysis included planning documents, government rules and regulations and government reports. Documentary analysis was also conducted across two major newspapers: Kompas and the Jakarta Post from 2010 to 2016 for topics of science and technology and research funding in order to complement the data. The two-tiered documentary analyses enabled the author to update and crosscheck information gathered from her fieldwork. Rather than resorting to a strict unit of analysis per individual or organisation, the author analysed and explored discourses and themes that resurfaced in her data. The next section outlines the challenges faced by academia in Indonesia's knowledge society.

\section{Managing challenges: historical, structural and lack of scientisation factors}

The initial challenge faced by academia stems from historical factors. The tradition of social science research in Indonesia lacks a robust policy and funding framework that supports high quality social science research. Consequently, as identified by McCarthy and Ibrahim (2010), researchers became involved in consultancy or project work, or served as advisors to the government, or accepted highranking positions in the administration. University research centres became reliant mainly on consultancy and were project orientated. On a prolonged basis, this decreased their ability to nurture their capacity for socially relevant research, to support collective research projects (McCarthy and Ibrahim 2010; see also Nugroho, 2005, 2012).

Waves of organisational changes have stemmed from the lack of vigorous government support for reforming universities. These changes are targeted at enabling universities to capitalise on external sources of funding, particularly from the market. At first, universities were restructured into State Owned Higher Education Autonomous Legal Entities (BHMN). They were, as McCarthy and Ibrahim (2010) suggest, more autonomous and generated their own revenues. Subsequently, the Directorate General for Higher Education (DIKTI) defined policies and funding schemes to support the research sector. However, this status of BHMN was ambiguous after the Constitutional Court decision annulled the legal basis of BHP (Educational Legal Entity). A transition phase was initiated until the end of 2012, during which the management of the universities regarded as BHMN was entrusted to the campus (Napitupulu and Mulyadi 2011). The government now uses the term "Universities Managed by the State" (perguruan tinggi yang diselenggarakan pemerintah/PTP) to refer to these universities. An example of such a university is the Bandung Technology Institute. Presently, a silver lining for universities' research funding can be seen in the current Law No. 12/2012, Article 89, on Higher Education, which stipulates that around 30 per cent of State University Operational Assistance Funds (BOPTN) could be allocated for research. This is in addition to the Non-Tax State Income (PNBP) from universities, which aggregates to IDR 300 to 400 million in total (Nugroho et al. 2016). Nonetheless, these changes are not backed by consensus among policy-makers regarding the direction of progress for Indonesian universities.

The overall science system in Indonesia has been in transition since 1945. Transition from the Dutch colonial power to the government of Indonesia was not smooth and triggered a process of knowledge loss. Pre-colonial Indonesia was characterised by Islamic education, was informal, and lacked structure. During the transition, two 
difficulties emerged: differences in languages and the duality of the system. These differences pertained to Dutch and Indonesian languages and also local languages. Translation of previous knowledge attained during the Dutch era was incomplete. At the same time, formal higher education, during the Dutch colonial era, was developed to meet the human resource demands of the colonial administration. The focus was geared more towards training than academic research (Buchori and Malik 2004). The government then separated the two systems: the Ministry of Education managed formal higher education and the Ministry of Religious Affairs administered Islamic higher education (Purwaningrum 2014). Currently, under President Jokowi's leadership, the Ministry of Research and Technology has been merged with Higher Education, whilst the Ministry of Education has been restructured into the Ministry of Education and Culture (see Nugroho et al. 2016).

Centralisation is due partly to historical factors. The New Order government, which was in power before reformasi in 1998, had been interventionist (Nugroho 2005). The Indonesian science system was largely centralised, with research themes being decided by the Ministry of National Education and the Ministry of Research and Technology (Purwaningrum 2014). Links with Jakarta, the capital of Indonesia, were vital. This was emphasised by an expert in BIC, who referred to a "regional innovation system", 5 which was and is the model pursued in Indonesia. The expert explained the top-down culture of the system, which suggests that change has to be driven by the president and the team in charge of implementation (Interview, Jakarta, 21 May 2010). Sherlock (2010) substantiates links with Jakarta in describing the flow of expert advice. He shows how expert advice is channelled through many means: in an informal way through think tanks, universities or consultancy firms to the national parliament, or leaders of commissions in the national parliament and in a formal way to formal meetings at the national parliament's internal sessions, including public hearings (Sherlock, 2010, pp.12-14). Despite the different channels, two similarities are evident: linkage is vital and advice is provided by individual researchers. In sum, a variety of historical predicaments are faced by academia in Indonesia. This has contributed to the problem from before Indonesia gained its independence in 1945 to the present day.
The term "structural" has been borrowed from sociologist Pierre Bourdieu (1992), who used to describe social structure. It essentially means that there are overarching structures existing through time and space. Structural predicaments faced by academia are macro conditions encountered due to the functioning of the science system. To begin with, coordination poses a major challenge, which includes the prevalent diverging interests of the ministries. This is exemplified in the planning activities undertaken by the Ministry of Industry and the Ministry of Research and Technology (RISTEK). RISTEK sets the national research agenda (Agenda Riset Nasional), which concentrates on funding in seven areas: food security; energy; technology and transportation management; information communication technology; defence and security technology; medicine and health technology; and advanced material (sciences) (Ristek 2006, 2011). The seven areas were still relevant in 2012-2014. According to a recent RISTEK performance report of 2014, which was published in 2015, the national innovation system still served as a paradigm for development priority, and the national research agenda continued to focus on the seven areas for 2005-2025 (Ristek 2015).

The sectoral approach contributes to the coordination challenges between ministries. Each ministry (i.e., RISTEK, the Ministry of Industry and Bappenas (National Planning and Development Agency)) seems driven by its own silo mentality, as evinced in the practices for managing budget and programmes. Budgets and programmes add to the problems of coordination between ministries. ${ }^{6}$ In fact, RISTEK, the Ministry of Industry and Bappenas are all concerned with the science policy, and each has its own programme (Interview, Jakarta, 10 August 2010).

In a discussion, RISTEK acknowledged the challenge of coordination between diverse ministries. Apart from setting priorities, which are distinct for each ministry, budgeting is also part of this issue. In this regard, a respondent stated how, when it comes to budgeting he does not want to disturb other people's pockets (Interview and Informal Discussion, Jakarta, 2 June 2010). Some experts believed that budgetary constraints have adversely affected researchers' performance in Indonesia. The lack of funds has inhibited researchers in Indonesia from carrying out the necessary networking for their research activities. 
First from the side of research and development, researchers in Indonesia do have networks and they share their (informational) activities. What makes it difficult is the institution (the organisation). The researchers are prohibited from doing activities (relating to their research and networking): this is due to organisational restraint. Why would organisations do this? This is due to budgetary considerations. (Interview, Jakarta, 14 June 2010)

A silo mentality has contributed to the lack of communication between ministries. Major research organisations in Indonesia such as RISTEK, the Research and Development Departments in the ministries of Indonesia and non-departmental research agencies such as the National Nuclear Agency, rarely communicate with each other to discuss and set the direction and goals of national policy on science (Tirtosudarmo 2014).

Structural challenges are not confined to budgets alone. Indonesia does not have the financial infrastructure in place to harness cuttingedge science and technology (Brodjonegoro and Greene 2012; Ribka 2016). In this study, the researcher identified that apart from budgetary problems and financial infrastructure, bureaucraticadministrative requirements and kickbacks also contributed to the situation (see Suryadarma et al. 2011), hampering academia, funded by the state, from excelling. Kickbacks or bribing have been impeding the production of knowledge in Indonesia. When asked about the constraints of knowledge production and knowledge flow, a high-level official in RISTEK stated his concerns based on his experience:

To be honest, this is sometimes due to a "sectoral ego" or a "personal ego". Especially when we do not know each other one would say, who are you? I do not need you in my work. In research activity, such model is not viable. We went to the Agency for Research and Development (Balitbang) of Ministry of Home Affairs in Indonesia recently: we have the impression if we are good (honest) and open, they will receive us well. There are several views from head of research centres (in Ministry of Home Affairs), perhaps they have had experiences which were not positive, saying that Insentif RISTEK grant should be bestowed directly to the researchers and not via the organisations as they are likely to be cut. Indeed, we want to make it simpler but we are restrained in terms of the administration; it is not possible to give Insentif RISTEK grant to individual researchers, there has to be a contractual obligation. (Interview, Jakarta, 17 May 2010)

This is not a stand-alone finding. Suryadarma et al. identify how payment for kickbacks in research contracts is common trend in the majority of government departments and local governments, with the percentage ranging from 5 to 40 per cent of the total value of the contract (2011, p.12). Such kickbacks reduce the quality of knowledge production from research funded by governments in Indonesia as then the goals are based on spending the budget, instead of publishing quality results and building the capacity of younger scholars.

Bureaucratic administrative requirements are particularly relevant to report-making. Reports known as LAKIP (Laporan Kinerja Instansi Pemerintah/Government Offices Performance Report) in government budget spending are made per government offices/unit (satuan kerja). The reports would more or less follow the spending that was made on the basis of the strategic planning (rencana strategis) of the ministry. The extent of the spending (penyerapan) of the budget has an implication for the next fiscal year budget allocation. The logic followed is that the less the intended spending, the lower the upcoming budget will be. This is, however, also subject to auditing, communication, and lobbying. The different units or offices in the ministry level are thus accountable in terms of LAKIP. $^{7}$ The extent of the spending of the budget per fiscal year requires teamwork within the unit, and the ministries in Indonesia have been fairly slow in spending the budget (Tanjung 2010). Extending the budget spending to other parties by working with different ministries is a precarious business, requiring trust between organisations, which is scarce.

What is also evident is a duplication of research proposals and programmes. This may result from a lack of coordination. The mapping of research carried out by the DRN in 2006-2007 showed 11 research projects on bio-fuel generated from palm, with a total funding of around IDR 15 billion, but these projects did not coordinate with each other in the implementation phase (DRN 2007; DRN 2010; Interview, Cibinong, 18 May 2010). In summary, a silo mentality that impedes coordination between ministries, duplication of research efforts, bureaucratic requirements, and kickbacks constitute the structural predicaments of academia in the Indonesian science system.

The next challenge is the lack of scientisation. Factors that contribute to this issue are individuals "moonlighting" as researchers or scholars, taking up two or three lecturer positions (see Purwaningrum 2014) in addition to their research 
commitments. McCarthy and Ibrahim (2010, pp.13-14) state that time restraints on mentoring the next generation of researchers is an added concern. Those who have the capability tend to be overcommitted to consultancy projects as a result of a model of research funding provided by PNBP (non-tax state revenue system) in Indonesia (see also Purwaningrum 2014; Suryadarma et al. 2011). The lack of scientisation occurs due to scarcity of basic social science research and renewal of scientific knowledge to the point that they reach a level of "abstraction" (Kuhn 1970) or "generalisation" (Agarwal 2002). The productivity of Indonesian scholars, in terms of published academic papers, is low $^{8}$ (Aliabbas and Tjahjono 2015). Scientific knowledge production requires not only "abstraction" or "generalisation" but also written publication which conforms to scientific norms. The second contributing factor to the lack of scientisation is the entrepreneurial orientation of research institutes. Such an orientation has come about because Indonesia"s PNBP (non-tax state revenue system) mechanism allows governmentfunded R\&D to maximise and benefit from its own income-generating activity as an organisation. Lack of scientisation is propelled by a strong orientation to entrepreneurial activity in Indonesia. This is exemplified in an organisational case study of Polymer Technology Center, located in Puspiptek Serpong, Tangerang.

The Sentra Teknologi Polimer (Polymer Technology Centre) was born out of a laboratory in 2001 under the auspices of BPPT (National Agency for the Application and Implementation of Technology). Financial assistance was received from a government-to-government loan from the Austrian Government in 1999-2000. This loan enabled training and the purchasing of state-of-the-art equipment to allow ST Polymer to function in the early stages after its inception. Training was also imparted internally to instil professional values in the day-to-day work of the employees. The intention was to be fully operational in terms of providing training, testing and other services related to plastics and polymer. In addition, efforts were made to dissociate from the image of inefficiency attached to the civil service in Indonesia.

In total, 1,200 companies have used Polymer Technology Center's services since 2002 (Informal discussion, Tangerang, 12 July 2010), with manufacturing (including automotive industries) accounting for 67 per cent. Various services are provided, including $\mathrm{R} \& \mathrm{D}$, training, testing, and technical assistance. Each of these services targets up-stream, mid-stream and down-stream segments of the industry.

Polymer Technology Center does not have the ambience of an office or laboratory such as that found in Cibinong Science Park in Indonesia. Its laboratories are located at the back of the office (Observation, 20 December 2010). They have various laboratories, including microbiology, thermal labs, and electrical. Ongoing training includes activities such as out-of-town visits to market products to companies. Various ISO certifications are implemented, including the ISO 9001 for management system quality to the ISO 9075 for quality testing. The core values of the organisation are creativity, care, vision, integrity, and professionalism, and these are prominently displayed in the meeting place and reception hall of the office.

Other distinct characteristics that lend the organisation an entrepreneurial essence include its close ties with plastic or polymer industries. In the past, the organisation has conducted two in-house research activities for generating income from customer/industrial clients. These were focused on polymer in asphalt research, and extracting biodegradable polymer from starch. Ideas for their patents and products are derived from discussions with industry members, before being researched, patented, and then marketed as products to the clients. Further, no income-supplementing activities are undertaken on weekdays. Each service accrued goes via a PNBP (non-tax state revenue system) mechanism, and bonuses are then added based on the work logged.

Although the entrepreneurial character of the organisation is commendable, it has also threatened to compromise the scientific character. Learning from the industries mostly occurs at the tacit level, leading, for example, to the development of the polymer in asphalt research. The human resource, totalling 39 people, is under significant work pressure as there are client deadlines to meet. Scientific publication is not a salient feature of the organisation, and overall the entrepreneurial character has led to the organisation functioning more as an industrial unit.

Each organisation does have its own epistemic culture. Yet institutions of academia such as the Polymer Technology Center are imbued with 
an expectation to produce not only products but also scientific knowledge. This is unfortunately not prominent at the centre. The ST Polymer, for example, is a case of government-funded academia being more entrepreneurial in character.

On the basis of these findings, the author contends that for a knowledge society to materialise, Indonesia has to cope with its structural and historical predicaments as well as the lack of scientisation. These challenges are intrinsic to the functioning of Indonesia's knowledge sector. To be able to manage these challenges, cultivating collaborations are vital. The ensuing sections explore the typology of collaborations existing at a macro and micro level.

\section{Cultivating collaborations: from friendly ties to industry as an initiative taker}

Collaborations for the production of knowledge are a viable opportunity in Indonesia. In this section, the author observes and analyses how social interactions facilitate collaborations, not only via intentional means such as social actions but also via unintentional means, as well as initiatives of the industry for collaboration. Collaboration will be discussed under the themes of collaboration between university and industry, sharing of budgets for research infrastructure, and the communication of information and expertise between diverse ministries.

Hubungan pertemanan, or a friendly association, enhances communication between the upper rungs of the ministries. Such friends-with-friends relations enable the transfer of expertise from one ministry to another research organisation and vice versa.

The approach is based on a collegial/friendship basis. For example, I was asked to be member of the supervision team for engine development. This is because I have good friendly relations. I advised them to develop 500cc engines for the Research Institute in Puspiptek Science Park (in Tangerang). (Interview, Jakarta, 10 August 2010)

This friendship-driven connection may be forged on the basis of alumnaeship. For example, the alumnae of mechanical engineering majors of the Bandung Technology Institute (ITB) keep in touch via a mailing list. Further, some of these alumnae exchange industry updates and information on projects undertaken in other ministries (Interview, Jakarta, 31 May 2010). This linkage is fluid in character and crosses the supposedly vertical hierarchical layers in the civil service. The connection is also termed as a personal approach (pendekatan personal), and the experience of working with colleagues strengthens the connection (Interview, Jakarta, 24 August 2010).

Trust is also enabled through such personal relations, which engenders cooperation for the flow of a variety of information. Nonetheless, the trust forged at this level of connection cannot be translated to the institutional level. Such connections build trust of a fragile nature, which only works within certain boundaries and not in the bureaucratic organisation. A respondent shared his own experience of the "fragility" of such trust.

In one of the SME (small and medium enterprises) projects, diverse ministries and LPNK were involved. I used the connection. I run the project in a smooth manner initially because their boss was also my boss with whom I had collaboration in the past. But this support was not translated in a manner that was expected. We are talking about certain LPNK here: they do not take it seriously. I know someone (high ranking official) in the Ministry of Industry. We have worked together in the past. But the staff that were appointed to work with me cannot communicate well. Yes, friendship connections matter, but once this trust is delegated to a level where teamwork is needed and if the staff have no clue, then there is an issue. (Interview, Jakarta, 2 August 2010)

Trust and friendship ties facilitate collaboration between academia and the government, and between the central government and the district or provincial government in Indonesia. The following paragraphs focus on a micro level collaboration between a university and the CHN company.

As mentioned earlier, the industry typically takes the lead in enabling knowledge to be produced and exchanged. In an interview with one of the highranking officials in RISTEK, this point was reiterated. He stated that the industry has to make the first move due to considerations of sustainability. He then added:

If the one who initiates this is a government research unit they will think of what would be interesting as a topic of research, or theories, but they do not think of whether the research will resolve existing issues or not. They are secured enough by doing so as they receive funding from the government, constantly, without considerations of where to go in terms of direction. (Interview, Jakarta, 3 June 2010) 
The case study for micro level collaboration involves an industrial organisation and a university: CHN Company and the Metallurgy Department of the University of Indonesia. The University of Indonesia (UI) is a state university that has undergone major changes. It was initially a BMHN prior to the reversal by the Constitutional Court decision in 2010. The university was founded in 1849 by a Dutch colonial governor. UI has two main campuses; the first is situated in the central business district at Salemba, Central Jakarta, and the second is located in the verdant settings of Depok, in West Java Indonesia (Universitas Indonesia 2015). The Metallurgy Department of the University of Indonesia is located in Depok, West Java Indonesia. This department has entered into a collaboration with CHN, a company which is a first-tier supplier of motorcycle braking systems to Honda Motors Indonesia. It is located in the industrial cluster of Jababeka.

The collaboration was unplanned and not premeditated. The cooperation between $\mathrm{CHN}^{9}$ and UI began in 2004. As part of a field visit, UI had arranged to visit another automaker. However, because that automaker could not accommodate the request, UI shifted its visit to $\mathrm{CHN}$. During the visit, an official from the top management had a discussion and agreed to open the process on the shop floor to the dean and lecturers at the Metallurgy Department, Faculty of Engineering, UI (Interview, Cikarang, 26 October 2010).

The specifics of the cooperation between $\mathrm{CHN}$ and the metallurgy department are as follows. UI may observe processes on the shop floor, use the testing facilities, and access the factory for the purposes of their study. The UI team can apply theories that they have learned on campus in the factory (Interview, Cikarang, 26 October 2010). This typology of knowledge is applied and is related to the production of materials, not the engineering process. It is not scientific knowledge. The knowledge being shared is limited to the materials for the parts. One of the staff members interviewed by the author suggested that in terms of technical know-how of the product being produced, i.e., the braking system, the advice that can be directly incorporated in production is not from the experts at UI but from the advisors or technical experts within the company (Interview, Cikarang, 8 October 2010). Thus, one can infer that the knowledge is not scientific in character and is related more to applied knowledge of metallurgical processes.

Applied knowledge as such has its limitations. CHN prefers its sources of knowledge to be the principal shareholding company or an in-house resource, in that order. UI is not mentioned as a source of knowledge. This is due to the fact that the daily interactions and problem-solving activities enable rapid assimilation of inputs from internal sources of knowledge. Another factor is the readiness of the lecturers or experts at UI. The experts or advisors in the company are recognised to have a greater sense of problem-solving. The professors working at UI are not ready to have specific discussions about the parts being produced; they are restricted to pure engineering process materials.

What enables this academia-industry collaboration is the fact that the latter has played the role of an initiator; those in charge of the cooperation are the CEO and the manager of CHN Company. The cooperation with UI is directly facilitated by key officials at top management level in CHN. This enables and legitimises the access and acceptance of the Metallurgy Department of UI.

The legitimacy and approval from the top management of the company enables the cooperation. Unlike the supplier and company relations, where the supplier would locate itself close to the customer to ensure timely delivery of good or parts, in the knowledge transfer between academia and industry geographical distance is not necessarily an issue. The company prefers to cooperate with UI rather than ITB, which is closer, as it is located in Bandung, because of the credibility assigned by a key official holding a position at the top level (Interview, Cikarang, 26 October 2010). The facilitation and legitimacy process fosters cooperation at a formal level of agreement on the shop floor. The endorsement from an expert in a high position in the organisation facilitates the usage of knowledge and transfer of expertise from UI to the company.

In other words, the expertise and position accorded to the person help in the implementation of the cooperation (see also Bourdieu 1992; Evers et al. 2010). This authorises the shop floor staff in the company to actively contact experts in UI. From a normative structure as shaped by the agreement, the authorisation granted via the legitimacy process by top management enables action within the relationship framework of UI and the company. 
Thus, the process of interaction between universities and industry requires an element of legitimacy from higher-level management within the company. However, to engage in such interaction, it is industry that has to make the first move.

Summing up, collaborations for knowledge production in terms of budget-sharing and flow of expert advice and knowledge are influenced by friendship ties and trust. A friendship tie, in particular, is nurtured through working experience and alumnae connections. Collaboration with industry will likely take place if the initiator is the industry itself rather than the research institute or university.

\section{Reflection and conclusion: knowledge society moving to an outward orientation with more scientisation?}

On the basis of his fieldwork in Indonesia in the 1970s, Clifford Geertz characterises intellectual life in Indonesia as being spasmodic, practical, centralised and robustly influenced by the economists (Geertz 1974). The issues of "spasmodic, centralised, and practical" were relevant even in 2005 when John McCarthy and Rustam Ibrahim investigated the major factors limiting the development of qualitative social science research capabilities in Indonesia. To date, the emphasis is on a "practical" orientation without musings and engagement with critical social science. Further, an aspect that is not sufficiently elaborated in McCarthy and Ibrahim's study or Geertz's study is that Indonesian scholars prefer to publish and write in the Indonesian language. This impedes the quick dissemination of knowledge.

The aim of this paper was explore the concept of a knowledge society and the possibility of it materialising in South East Asia. The study has identified that Indonesia's knowledge society has to cope with key challenges pertaining to historical, structural, and scientisation factors. Historical factors include partitioning of the Indonesian higher education system, centralisation, a lack of tradition of high-quality social science research, limited alumni networking among private universities located outside of Java island, knowledge loss during the transition from Dutch colonial power to the government and lack of strong commitment from the government to organisational changes in universities. Structural problems pertain to duplication of research proposals and programmes, bureaucratic administrative requirements, budgetary constraints, kickbacks and poor coordination efforts, the presence of a silo mentality and internal linkages within government ministries. The scientisation of social action is declining in Indonesia, and the academia-industry collaboration is less influenced by scientific knowledge. The micro-site findings in this study support this argument. An organisation pursuing research and development in polymers is losing its scientific character and reorienting itself to cater to the needs of market.

However, these challenges do not imply that collaborations between governmental departments or between the government and academia are an exception. Macro-level data analysis suggests that collaboration is facilitated by the presence of friendship ties and trust. Micro-level data analysis shows how the industry plays a key role in the initiation of collaboration. Yet within the ambit of academia and academia-industry collaboration for the production of knowledge, collaborations are less influenced by scientific knowledge. The analysis also indicates how experts basing their advice on scientific authority - which is possible thanks to scientisation - are dealing with problems where their advice does not meet the social reality of material engineering processes.

Given the predicaments faced by academia and the implications of collaborating with the market and/or with the government, it is likely that Indonesia's knowledge society works in an inward manner: it produces knowledge for the consumption and needs of those in Indonesia. International collaborations with researchers outside Indonesia are needed, with outputs in Indonesian and English, apart from long-term capacity-building that is not donor-oriented. Taking stock of past international research projects is vital in so far as actors such as scientists and universities can refer back to the stock of scientific knowledge. A donor orientation and/or a complete market orientation will only amount to recycling a past problem. Hence, this author calls for a critical examination of the scientisation process. There is also a need for the use of national science indicators and science in shaping scientific knowledge production, and involving other actors in the science system to dispel an ivorytower effect in producing scientific knowledge. 
Qualitative research (see Ritchie 2003) on a knowledge society can highlight why society needs knowledge as well as the forces and influences that prevent knowledge from being capitalised fully in order for a society to progress. Empirical studies of knowledge societies in Asia should inform experts on how far Indonesia's transition has progressed in terms of capitalising on knowledge. Efforts need to be undertaken to engage in critical (social) science knowledge production."

\section{Notes}

1. Since scientisation is a point of analysis, the author focuses on the science system when discussing actors in Indonesia's knowledge society.

2. This definition is conceptualised by taking into account Boehme and Stehr's work (1986) on knowledge society. See page <insert correct page no $>$ of this paper for Stehr and Boehme's definition of scientisation.

3. Actors included in these two aspects were policy-makers working in Bappenas (National Development and Planning Agency); RISTEK (Ministry of Research and Technology, currently referred to as the Ministry of Research,

Technology and Higher Education or RISTEK-DIKTI); BPPT (Agency for Assessment and Application of Technology); LIPI (Indonesian Institute of Sciences); BTC (Business Technology Center); BIC (Business Innovation Center); Ministry of Industry; Kemenko Perekonomian (Coordinating Ministry for Economic Affairs); Provincial Government of Jakarta and CHN Company, located in Jababeka Industrial Cluster. The author did not manage to secure any interview appointments with the Ministry of Higher Education in 2010-2011.

4. These meetings were organised either by RISTEK (Ministry of
Research and Technology) or Business Innovation Center or Bandung Technology Institute (ITB) on the following dates: 24-26 May 2010, 24 June 2010, 23 October 2010, 30 July 2010, 8 October 2010 , 5 August 2010, 13 August 2010, 12 October 2010.

5. A regional innovation system (RIS) or Sistem Inovasi Daerah (SIDa) is a model being adopted and implemented by the government of Indonesia. It is defined as a complete system that promotes innovation carried out by central government, local government, R\&D research centres, higher education institutions, innovation-supporting agencies, companies, and society in the region. See Joint Government Regulation between Ministry of Research, Technology and Higher Education No. 3 Year 2012 and Ministry of Home Affairs No. 36 Year 2012. The coordinator of RIS/SIDa will be the Regional Research and Development Agency (Badan Penelitian dan Pengembangan Daerah/BPPD), as outlined in the Ministry of Research, Technology and Higher Education Strategic Plan for 2015-2019 (RISTEK-DIKTI 2015).

6. This was highlighted in interviews with officials in RISTEK, Bappenas, (National Development and Planning Agency) as well as the
Ministry of Industry in May 2010-June 2010.

7. LAKIP is a part of the System of Accountability of Performance of Government Offices drafted in line with Presidential Instruction No. 7 Year 1999.

8. Productivity in terms of published academic papers by Indonesian scholars is still low. Aliabbas and Tjahjono (2015) showed that, based on scimagojr.com, from 1996 to 2013, Indonesian scholars published 25,481 papers internationally. This is below average of other countries such as Malaysia (125,084 papers).

9. The initials of the company have been used; here it is abbreviated as CHN.

*An earlier version of the paper was presented at ECPR General Conference 2015 in Montreal, Canada. I am thankful to ZEF, University of Bonn and DAAD, Germany for the scholarship and fieldwork grant enabling the data collection in 2009-2012 for this paper. Meng Hsuan Chou, Anastasiya Shtaltovna and Azizi Fakhri gave valuable comments in earlier draft versions of the paper. Ratnasari Nugraheni assisted in reference and editing support. Two anonymous reviewers provided constructive feedback, for which I am grateful.

\section{References}

Agrawal, A., 2002. Indigenous knowledge and the politics of classification. International Social Science Journal, 173, 325-336.
Ambrosini, V. And Bowman, C., 2001.

Tacit knowledge: some suggestions for 
operationalization. Journal of

Management Studies, 38(6), 812-829.

Aliabbas, A. and Tuahjono, B., 2015.

The need for a progressive policy to boost innovation. The Jakarta Post, 26 May 2015. Available online at http:// www.thejakartapost.com/news/2015/05/ 26/the-need-a-progressive-policyboost-innovation.html [accessed on 10 June 2016].

Aminullah, E., 2012. Coping with low R\&D investment in Indonesia: policy insights from system dynamics model. Journal of $S \& T$ Policy and $R \& D$ Management, 10(1), 1-10.

Bappenas and Australian Aid, 2015. Knowledge sector initiative. http://www.ksi-indonesia.org/index .php/publications/2015/08/10/14/ diagnostic-studies-on-the-knowledgesector.html [accessed on 13 June 2016].

BELL, D., 1973. The coming of post-industrial society. New York: Basic Books Inc.

Böhme, G. And Stehr, N. 1986. The knowledge society. In: G. Böhme and N. Stehr, eds. The growing impact of scientific knowledge on social relations. Boston: D. Reidel Publishing Company.

Bourdieu, P., 1992. Language and symbolic power. Cambridge, UK: Polity Press.

Brodjonegoro, S. S. And Greene, M. P., 2012. Creating an Indonesian Science Fund. Indonesian Academy of Sciences. Jakarta: World Bank and AusAID.

Buchori, M. And Malik, A., 2004. The evolution of higher education in Indonesia. In: P. G. Altbach and T. Umakoshi, eds. Asian universities: historical perspectives and contemporary challenges. Baltimore: Johns Hopkins University Press, 249-278.

Chen, K. And Kenney, M., 2007. Universities/research institutes and regional innovation systems: the cases of Beijing and Shenzen. World Development, 35 (6), 1056-1074.

Clark, B., 1998. Creating entrepreneurial universities: organizational pathways of transformation. New York: Pergamon.

Crossley, N., 2010. Towards relational sociology. New York: Routledge.

DeEm, R., 2001. Globalisation, new managerialism, academic capitalism and entrepreneurialism in universities: is the local dimension still important? Comparative Education, 37(1), 7-20.

Drn, 2007. Tentative result of the research mapping in the fiscal year of 2007. National Research Council. Jakarta: National Research Council of Indonesia (Dewan Nasional Riset/DRN), 1-47.

Drn, 2010. National Research Agenda. Jakarta: National Research Council of Indonesia (Dewan Nasional Riset/DRN).

Evers, H.-D., 2003. Transition towards a knowledge society: Malaysia and Indonesia in comparative perspective. Comparative Sociology, 2(2).

Evers, H.-D., Kaiser, M. ANd MüLler, C., 2009. Knowledge in development: epistemic machineries in a global context. International Social Science Journal, 60 (195), 55-68.

FISCHER, M., 2011. About the half-life of work-related knowledge vocational education and training in a knowledge-based society. In: B.-J.

Krings, ed. Brain drain or brain gain? Changes of work in knowledge-based societies. Berlin: Edition Sigma, 177-204.

Fuller, S., 1997. Concepts in the social sciences, science. Buckingham: Open University Press.

FulLer, S., 2000. The governance of science. Buckingham: Open University Press.

GeErTz, C., 1974. Social science policy in a new state: a programme for the stimulation of the social sciences in Indonesia. Minerva, 12(3), 365-381.

Gibbons, M., Limoges, C. et al., 1994.

The new production of knowledge: the dynamics of science and research in contemporary societies. Stockholm: Sage Publications.

Giddens, A., 1979. Central problems in social theory: action, structure and contradiction in social analysis. London: Macmillan.

Guardian, 2013. Working class students shun top universities, says study. Available online at http:// www.theguardian.com/education/2013/ nov/13/working-class-students-shuntop-universities [accessed on 10 August 2015].

Hakansta, C. And Jacob, M., 2016. Mode 2 and the tension between excellence and utility: the case of a policy-relevant research field in Sweden. Minerva, 54, 1-20.

Hansen, M. T., Nohria, N. et al., 1999. What's your strategy for managing knowledge? Harvard Business Review, March-April 1999.

Harloe, M. and Perry, B., 2004. Universities, localities and regional development: the emergence of the "Mode 2 University"? International Journal of Urban and Regional Research, 28(1), 212-223.

HAYEK, F., 1945. The use of knowledge in society. American Economic Review, XXXV(4), 519-530.

Hornidge, A.-K., 2007. Knowledge society: vision \& social construction of reality in Germany and Singapore. Muenster: LIT Verlag.

Hornidge, A.-K., 2011. 'Knowledge society' as academic concept and stage of development: a conceptual and historical review. In: T. Menkhoff, H.-D. Evers, C. Y. Wah and E. F. Pang, Beyond the knowledge trap: developing Asia's knowledge-based economies. Singapore: World Scientific Publishing, 87-128.

Kunn, T. S., 1970. The structure of scientific revolutions. Chicago: University of Chicago Press.

KRINGS, B.-J., 2011. Introduction. In: B.-J. Krings, ed. Brain drain or brain gain? Changes of work in knowledge-based societies. Berlin: Edition Sigma, 11-29.

Knorr-Cetina, K., 1999. Epistemic culture: how the sciences make knowledge. Cambridge: Harvard University Press.

Knorr-Cetina, K. and Cicourel, A. V., 2015. Advances in social theory and 
methodology: towards an integration of micro- and macro-sociologies. London and New York: Routledge.

Koecker, G. M. and Saxena, S., 2012. Indicator-based analysis of national innovation systems: Indonesia. Summarising report of the determinants of the Indonesian innovation system. Institute for Innovation and Technology, Berlin and Federal Ministry of Education and Research (BMBF) Germany. http://www.iit-berlin.de/de/ publikationen/indonesia/at_download/ download [accessed on 10 June 2016].

LeyesdorfF, L., 2012. The triple helix, quadruple helix, ..., and an n-tuple of helices: explanatory models for analyzing the knowledge-based economy? Journal of Knowledge Economy, 3, 25-35.

LeOnARD-BARton, D., 1992. The factory as a learning laboratory. Sloan Management Review, 34, 23-38.

LoH, B., TANG, A.-C. et al., 2005. Applying knowledge management in university research governing and managing knowledge in Asia. In: T.

Menkhoff, H.-D. Evers, C. Y. Wah and E. F. Pang, eds. Beyond the knowledge trap: developing Asia's knowledge-based economies. Singapore: World Scientific Publishing.

MAY, T., 2001. Social research: issues, methods and process. Philadelphia, Buckingham: Open University Press.

MAy, T. AND Perry, B. 2011. Social research \& reflexivity: content, consequence and context. LA, London, New Delhi, Singapore, Washington, DC: Sage.

MCCARThy, J. AND IBRAhim, R., 2010. Review of social science capacity building support to Indonesia's knowledge sector. Mimeograph, available online at http://dfat.gov. au/about-us/publications/Documents/ indo-ks9-socialscience.pdf [accessed on 9 August 2015].

Menko-Perekonomian, 2011. Masterplan for the acceleration and expansion of Indonesia economic development 2011-2025 K.K.B. Perekonomian. Jakarta: Menko-Perekonomian, 1-207.
Müller, C., 2005. Between oral history and ICT: on the creation of knowledge societies. University of Bielefeld Working Papers No. 348: Universität Bielefeld https://www.unibielefeld.de/\%28de\%29/tdrc/ag sozanth/publications/working_papers/ Wp348.pdf [accessed on 31 December 2015].

Napitupulu, E. L. And Mulyadi, A., 2011. The transition phase of state owned legal entity is given to the campus (Masa Peralihan PTN BMHN Diserahkan ke Kampus). Jakarta: Kompas.

Nugroho, H., 2005. The political economy of higher education: the university as an arena for the struggle for power. In: V. R. Hadiz and D. Dhakidae eds Social science and power in Indonesia. Singapore: Institute of Southeast Asian Studies, 143-165.

Nugroho, H., 2012. State, university and banality of intellectual: a critical reflection from the inside. Professorial inauguration speech delivered at Gadjah Mada University. Yogyakarta: Gadjah Mada University, 1-25.

Nugroho, Y., Prasetiamartati, B. et al., 2016. Addressing barriers to university research. Working paper 8: Knowledge sector initiative. Jakarta: Kementrian PPN/Bappenas and Australian Aid.

Pfister, T., 2009. Governing the knowledge society: studying Lisbon as epistemic setting. In: S. Kröger, ed. What we have learnt: advances, pitfalls and remaining questions in OMC research, European Integration online Papers (EIoP), Special Issue 1, Vol. 13, Art. 6, http://eiop.or.at/ eiop/texte/2009-006a.htm.

Pestre, D., 2003. Regimes of knowledge production in society: towards a more political and social reading. Minerva, 41, 245-261.

Pestre, D. and Wiengart, P., 2009.

Governance of and through science and numbers: categories, tools and technologies - preface. Minerva, 47(3), 241-242.

Pinheiro, R. and Stensaker, B., 2014. Designing the entrepreneurial university: the interpretation of a global idea. Public Organization Review, 14, 497-516.

Purwaningrum, F., 2014. Knowledge governance in an industrial cluster.

The collaboration between academia-industry-government in Indonesia. Berlin and Zürich: LIT Verlag.

RAMMERT, W., 2002. The governance of knowledge, limited: the rising relevance of non-explicit knowledge under a new regime of distributed knowledge production. Technical University Technology Studies, Working Papers TUTS-WP-1-2002. Berlin: Institut für

Sozialwissenschaften, Fachgebiet Techniksoziologie.

RiBKA, S., 2016. Agency to offer simplified access to research finding. The Jakarta Post, 7 April 2016.

Available online at http://www.thejakartapost.com/ news/2016/04/07/agency-offersimplified-access-researchfunding.html [accessed on 10 June 2016].

Ristek, 2006. Buku Putih: Indonesia 2005-2025-Penelitian Pengembangan dan Penerapan Ilmu Pengetahuan dan Teknologi. Jakarta: Ministry of Research and Technology (Kementerian Riset dan Teknologi/RISTEK).

RISTEK, 2011. Strategic national planning for science and technology in the year 2010-2014 (Kebijakan Strategis Pembangunan Nasional Ilmu Pengetahuan dan Teknologi tahun 2010-2014). Jakarta: Ministry of Research and Technology (Kementerian Riset dan Teknologi/RISTEK), 1-40.

RISTEK, 2015. Performance accountability report 2014. http://www.ksi-indonesia.org/index. php/publications/2015/08/10/14/ diagnostic-studies-on-the-knowledgesector.html [accessed on 09 June 2016].

RisteK-DikTi, 2015.Strategic national planning for the Ministry of Research, Technology and Higher Education 2015-2019 (Rencana Strategis Kementerian Riset, Teknologi dan Pendidikan Tinggi Tahun 2015-2019). Jakarta: Ministry of Research, 
Technology and Higher Education (Kementerian Riset, Teknologi dan Pendidikan Tinggi/RISTEK-DIKTI), 1-62.

Ritchie, J., 2003. The applications of qualitative methods to social research. In: J. Ritchie and J. Lewis, eds.

Qualitative research practice: a guide for social science students and researchers. London: Thousand Oaks, New Delhi: SAGE Publications, 24-46.

Slaughter, S. and Rhodes, G., 2004. Academic capitalism and the new economy: markets, state and higher education. Baltimore, N.J: Johns Hopkins University Press.

STEHr, N., 2007. Wissenspolitik. Frankfurt am Main: Suhrkamp.

Stehr, N. and Ulrich U., 2009. On the global distribution and dissemination of knowledge. International Social Science Journal, 195, 7-24.

Subejo, 2010. The performance of research in Indonesia. The Jakarta Post, 2 July 2010. Available online at http://www.thejakartapost.com/news/ 2010/07/02/the-performance-research- indonesia.html [accessed on 10 June 2016].

Suryadarma, S., Pomeroy, J. et al., 2011. Economic factors underpinning constraints in Indonesia's knowledge sector. Final Report. AusAID Agreement No. 58216. Jakarta: Ausaid's Tertiary Education and Knowledge Sector Unit. Available online at https://dfat.gov.au/aboutus/publications/Documents/indo-ks2economic-incentives.pdf [accessed on 9 August 2015].

Tirtosudarmo, R., 2014. Science and technology policy: where are we going? The Jakarta Post, 1 April 2014. Available online at http://www.thejakarta post.com/news/2014/04/01/scienceand-technology-policy-where-are-wegoing.html [accessed on 10 June 2016].

Tsoukas, H., 2005. Complex knowledge studies in organizational epistemology. Oxford: Oxford University Press.

UnIVERSITAS-INDONESIA, 2015. History. Available online at http://old.ui.ac.id/ en/profile/page/history [accessed on 12 August 2015].
ValimaA, J. And Hoffman, D., 2008.

Knowledge society discourse and higher education. Higher Education, 56 (3), 265-285.

Vostal, F., 2013. Should academics adopt an ethic of slowness or ninja-like productivity? In search of scholarly time. LSE Impact of Social Science, 20 November. Available online at http:// blogs.lse.ac.uk/impactofsocialsciences/ 2013/11/20/in-search-of-scholarlytime/ [accessed on 13 September 2016].

Weingart, P., 2002. The moment of truth for science the consequences of the 'knowledge society' for society and science. EMBO Reports, 3(8), 1-4.

Ye, R. And Nylander, E., 2015. The transnational track: state sponsorship and Singapore's Oxbridge elite. British Journal of Sociology of Education, 36 (1), 11-33.

YLIJOKI, O.-H., 2014. University under structural reform: a micro level perspective. Minerva, 52, 55-74.

Zellner, C. ANd Fornahl, D., 2002. Scientific knowledge and implications for its diffusion. Journal of Knowledge Management, 6(2), 190-198. 